\title{
Bunching Onion Culture in Greenhouse and Hoop House
}

\author{
Vincent M. Russo ${ }^{1}$ \\ U.S. Department of Agriculture, Agricultural Research Service, South Central \\ Agricultural Research Laboratory, 911 Highway $3 \mathrm{~W}$, Lane, OK 74555
}

\author{
James Shrefler \\ Oklahoma State University, Wes Watkins Agricultural Research and Extension \\ Center, P.O. Box 128, Lane, OK 74555
}

Additional index words. organic, planting date, protected culture, yield

\begin{abstract}
Extending the season can provide opportunities for vegetable producers. Bunching onion, or scallions (Allium fistulosum L.), is a crop that can be a candidate for protected production used to extend the growing season. The cvs. Evergreen Hardy White (white), Deep Purple (red), and Nabechan F1 (white) were sown at monthly intervals from Sept. 2010 to Aug. 2011 in containers under greenhouse and hoop house conditions at Lane, OK. Days to harvest and yield variables were determined. Crop failure occurred in a greenhouse for all plants sown in July, for 'Deep Purple' sown in August, and for those sown in a hoop house in February and March and May through August, days to harvest was generally less for plants sown in the greenhouse, and for 'Deep Purple', but all plants took longer to reach marketable size than is indicated for field production. Yields for plants grown in the greenhouse were higher than for those grown in the hoop house. Greenhouse production provides more flexibility and protection from environmental conditions so that bunching onions can be grown for extended season production. However, environmental controls under greenhouse conditions need to be refined to reduce length of growing season while maintaining, or improving, yields of optimally sized plants. Programs to improve nutrition in school systems and introduction of "Farm to School" and "extended season" initiatives present opportunities for production of some vegetables including bunching onion, or scallions. "Farm to School" programs allow the use of fresh, locally grown foods to be incorporated into school menus. Bunching onions can be used fresh or prepared items. Use of protected culture in greenhouses and hoop houses may allow for extended season production of these onions so that they can be used during non-typical growing periods especially, when locally produced field-grown crops are not available.
\end{abstract}

There is information on production of bunching onions under field conditions (Anonymous, 2002; Boyhan et al., 2009; Hodges, 2004). Expected yields from field

\footnotetext{
Received for publication 7 June 2012. Accepted for publication 10 Sept. 2012.

The U.S. Department of Agriculture (USDA) prohibits discrimination in all its programs and activities on the basis of race, color, national origin, age, disability, and, where applicable, sex, marital status, familial status, parental status, religion, sexual orientation, genetic information, political beliefs, reprisal, or because all or part of an individual's income is derived from any public assistance program. (Not all prohibited bases apply to all programs.) Persons with disabilities who require alternative means for communication of program information (Braille, large print, audiotape, etc.) should contact USDA's TARGET Center at (202) 720-2600 (voice and TDD). To file a complaint of discrimination, write to USDA, Director, Office of Civil Rights, 1400 Independence Avenue, SW, Washington, DC 20250-9410, or call (800) 795-3272 (voice) or (202) 720-6382 (TDD). USDA is an equal opportunity provider and employer. The article is work product of a U.S. government employee and there is no copyright to transfer.

${ }^{1}$ To whom reprint requests should be addressed; e-mail russo_vincent@hotmail.com.
}

affected by planting date and type of protected culture.

\section{Materials and Methods}

Untreated seed of bunching onion cvs. Nabechan F1 (white), Evergreen Hardy White (white), and Deep Purple (red) (Johnny's Selected Seed, Winslow, MA) were used. Under field conditions, seed can be sown in spring or late summer with harvestable size obtained from 60 to $65 \mathrm{~d}$ after sowing. This limits availability for other times of the year.

For this study a climate-controlled, glasspaned greenhouse and a minimally climatecontrolled hoop house were used. The greenhouse climate was controlled by an automatic system, which regulated air temperatures using circulated hot water in the cooler months and swamp coolers and automated ventilation in the hot months. The hoop house was covered with polyethylene plastic (6 mil, single layer, ultraviolet-treated) purchased locally from Leon's Greenhouses, Kingston, OK, and had no other heating or cooling. In the greenhouse, heating or cooling set points during the day and night were triggered at $\approx 24{ }^{\circ} \mathrm{C}$. No other modification was made to the greenhouse growing environment for the duration of the experiment. In the hoop house, plastic sides were raised and end doors opened in an attempt to alleviate effects of high temperatures. Sides were lowered and doors closed during the cooler months.

Organic methods and materials were used. Plastic containers $32 \times 18.5 \times 11.5 \mathrm{~cm}$ in length, width, and depth (5.7-L volume; surface area $0.06 \mathrm{~m}^{2}$ ) were used. Six holes ( $5 \mathrm{~mm}$ diameter) were drilled in container bottoms for drainage. Containers were filled to approximately a $10-\mathrm{cm}$ depth with moistened Sunshine potting mix [Sun Gro Horticulture, Bellevue, WA; Organic Materials Review Institute (OMRI) listed]. Untreated seed of each cultivar were planted in four rows per container starting $4 \mathrm{~cm}$ in from a long edge with rows $\approx 4 \mathrm{~cm}$ apart with an inrow seed placement of $\approx 2 \mathrm{~cm}$.

Plants were established on 15 Sept., 14 Oct., 16 Nov., and 15 Dec. 2010 and 21 Jan., 15 Feb., 15 Mar., 15 Apr., 15 May, 15 June, 15 July, and 15 Aug. 2011. Containers with seed were maintained in the greenhouse or hoop house. The greenhouse had $\approx 70 \mathrm{~m}^{2}$ in floor area and the hoop house had $\approx 90 \mathrm{~m}^{2}$ in floor area. Containers were maintained on metal benches $1 \mathrm{~m}$ above the floor in the greenhouse and on the soil floor in the hoop house.

Beginning 1 week after sowing, plants were fertilized weekly with $500 \mathrm{~mL}$ per container of a $16 \mathrm{~mL} \cdot \mathrm{L}^{-1}$ solution of Neptune's Harvest, 2N-3P-1K (Ocean Crest Seafoods, Gloucester, MA; OMRI listed; Russo, 2006) with subsequent fertilizations using the same rate and volume at two-week intervals. Containers with seed, and later emerged plants, were irrigated with a misting system in both structures. Irrigation was timercontrolled and events occurred at 9:00 AM, 
3:00 PM, and 6:00 PM daily with 3-min durations. Plants were exposed only to ambient daylight. Plants were maintained until pseudostems began to swell and/or tops began to degrade. There were no synthetic pesticides used; insect populations did not warrant control. Data were collected on days until harvest and marketable and cull number of plants produced; fresh weights of marketable and cull plants; weights of leaf tissue above a $20-\mathrm{cm}$ height, which would be removed to produce marketable size plants; and dry weight of marketable plants, which was determined based on USDA, AMS (U.S. Department of Agriculture, Agricultural Marketing Service, 1947) grades.

The experiment was arranged in a splitsplit plot with type of culture method (greenhouse vs. hoop house) being the main effect, monthly planting date (12) the first split, and cultivar (three) the second split arranged randomly within planting date. Each type of culture, planting date, and cultivar treatment was replicated three times. Data were subjected to analysis of variance (ANOVA) in PROC GLM in SAS (Version 9.1; SAS, Inc., Cary, NC). If interactions were significant, they were used to explain the data. If interactions were not significant, the Ryan-GabrielEinot-Welsch post hoc test was used to separate means.

\section{Results}

Day and night temperatures (Fig. 1) likely affected results. Day and night air temperatures gradually dropped from 15 Sept. with several nights being below freezing. Although daytime air temperatures began to rebound by late January, there were nights with air temperatures below freezing through midApril. Day and night air temperatures from April through September exceeded norms with several days being above $37{ }^{\circ} \mathrm{C}$ and nights above $22^{\circ} \mathrm{C}$. Air temperatures began to moderate from late September and nights with below freezing temperatures occurred from mid-October through the end of the experiment.

Days to harvest varied as a result of cultivar, planting date, and culture method (Table 1). In the greenhouse, 'Deep Purple' had among the shortest times to harvest. The exceptions were for the 15 July 2011 planting date when there were no harvestable plants produced for any cultivar and the 15 Aug. 2011 planting date when there was no harvestable yield for 'Deep Purple'. Under hoop house conditions, there was less variation in time to harvest but when it did exist, 16 Nov. and 15 Dec. planting dates, 'Deep Purple' had the shortest time to harvest. In the greenhouse, there was no consistent shortest average time to harvest over cultivars. In the hoop house, the shortest time to harvest over cultivars was for the 15 Apr. 2011 planting. Under greenhouse conditions, time to harvest was generally less than for the hoop house.

The ANOVA analysis (Table 2) indicated that main effects of culture method, planting date, and cultivar and their interactions affected all measured variables. The culture method by planting date interaction affected all but marketable dry weights. The culture method by cultivar affected all variables. The planting date by cultivar affected all but the weight of tops above $20 \mathrm{~cm}$. The culture method by planting date by cultivar affected all variables. There were exceptions

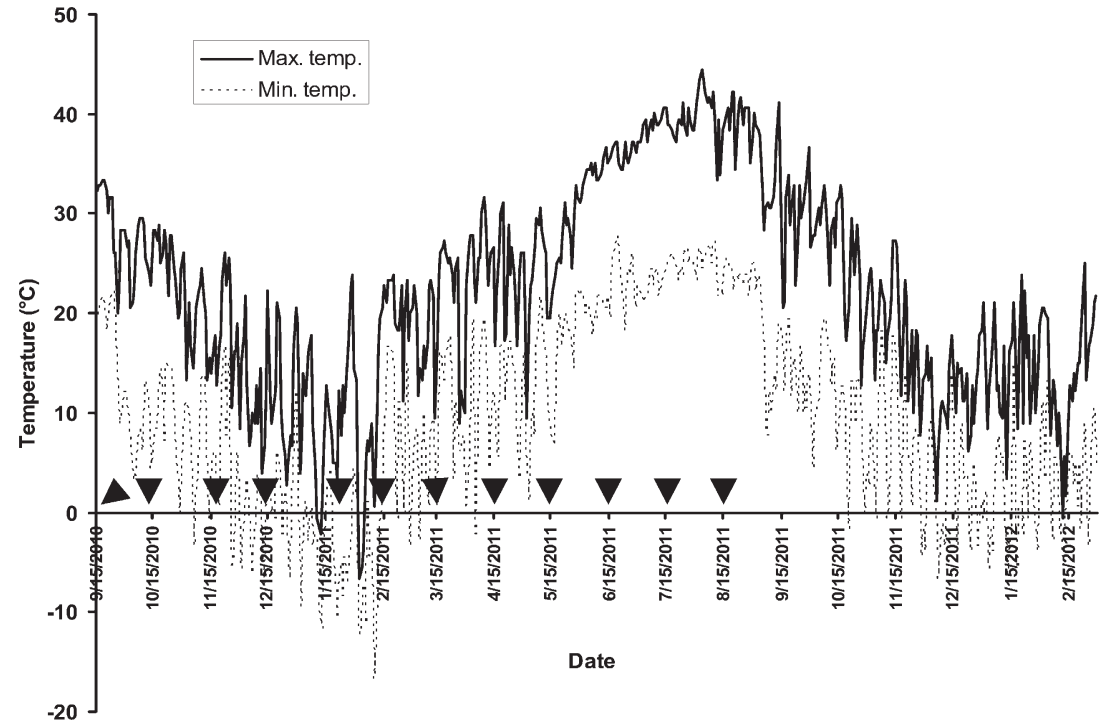

Fig. 1. Maximum and minimum temperatures over the growing period. Arrows indicate sowing dates in the greenhouse and hoop house.

Table 1. Days to harvest for bunching onion cvs. sown at various planting dates and cultured in a greenhouse or hoop house.

\begin{tabular}{|c|c|c|c|}
\hline \multirow[b]{2}{*}{ Planting date } & \multirow[b]{2}{*}{ Cultivar } & \multicolumn{2}{|c|}{ Days to harvest } \\
\hline & & Greenhouse & Hoop house \\
\hline \multirow{3}{*}{15 Sept. 2010} & Evergreen Hardy White & 143 & 174 \\
\hline & Deep Purple & 111 & 127 \\
\hline & Nabechan F1 & 138 & 127 \\
\hline \multirow[t]{3}{*}{15 Oct. 2010} & Evergreen Hardy White & 152 & 173 \\
\hline & Deep Purple & 125 & 173 \\
\hline & Nabechan F1 & 145 & 173 \\
\hline \multirow[t]{3}{*}{16 Nov. 2010} & Evergreen Hardy White & 156 & 189 \\
\hline & Deep Purple & 125 & 140 \\
\hline & Nabechan F1 & 139 & 163 \\
\hline \multirow[t]{3}{*}{15 Dec. 2010} & Evergreen Hardy White & 183 & 160 \\
\hline & Deep Purple & 110 & 134 \\
\hline & Nabechan F1 & 153 & 160 \\
\hline \multirow[t]{3}{*}{21 Jan. 2011} & Evergreen Hardy White & 158 & 158 \\
\hline & Deep Purple & 97 & 158 \\
\hline & Nabechan F1 & 158 & 158 \\
\hline \multirow[t]{3}{*}{15 Feb. 2011} & Evergreen Hardy White & 150 & $-^{z}$ \\
\hline & Deep Purple & 77 & - \\
\hline & Nabechan F1 & 150 & - \\
\hline \multirow[t]{3}{*}{15 Mar. 2011} & Evergreen Hardy White & 141 & - \\
\hline & Deep Purple & 133 & - \\
\hline & Nabechan F1 & 141 & - \\
\hline \multirow[t]{3}{*}{15 Apr. 2011} & Evergreen Hardy White & 193 & 103 \\
\hline & Deep Purple & 102 & 103 \\
\hline & Nabechan F1 & 193 & 101 \\
\hline \multirow[t]{3}{*}{15 May 2011} & Evergreen Hardy White & 148 & - \\
\hline & Deep Purple & 83 & - \\
\hline & Nabechan F1 & 148 & - \\
\hline \multirow[t]{3}{*}{15 June 2011} & Evergreen Hardy White & 251 & - \\
\hline & Deep Purple & 208 & - \\
\hline & Nabechan F1 & 232 & - \\
\hline \multirow[t]{3}{*}{15 July 2011} & Evergreen Hardy White & - & - \\
\hline & Deep Purple & - & - \\
\hline & Nabechan F1 & - & - \\
\hline \multirow[t]{3}{*}{15 Aug. 2011} & Evergreen Hardy White & 191 & - \\
\hline & Deep Purple & - & - \\
\hline & Nabechan F1 & 191 & - \\
\hline
\end{tabular}

z"_-" indicates there was no marketable harvest for the planting date, but some cull plants could have been produced. 
Table 2. Analysis of variance results for effects of protected culture method, cultivar, and planting date on yield characteristics of bunching onions.

\begin{tabular}{|c|c|c|c|c|c|c|c|}
\hline \multirow[b]{2}{*}{ Source } & \multicolumn{4}{|c|}{ Marketable } & \multicolumn{2}{|c|}{ Cull } & \multirow{2}{*}{$\begin{array}{c}\text { Top wt above } \\
20 \mathrm{~cm}\end{array}$} \\
\hline & Number & Yield & Dry wt & Yield per $\mathrm{m}^{2}$ & Number & Yield & \\
\hline Culture method (C) & $* *$ & $* *$ & $* *$ & $* *$ & $* *$ & $* *$ & $* *$ \\
\hline Planting date $(\mathrm{P})$ & $* *$ & $* *$ & $* *$ & $* *$ & $* *$ & $* *$ & $* *$ \\
\hline Cultivar (Cv) & $* *$ & $* *$ & $* *$ & $* *$ & $* *$ & $* *$ & $* *$ \\
\hline \multicolumn{8}{|l|}{ Interaction } \\
\hline $\mathrm{C} \times \mathrm{P}$ & $* *$ & $* *$ & NS & $* *$ & * & $*$ & $* *$ \\
\hline $\mathrm{Cv} \times \mathrm{C}$ & $* *$ & $* *$ & $* *$ & $* *$ & $* *$ & $* *$ & $* *$ \\
\hline $\mathrm{Cv} \times \mathrm{P}$ & $* *$ & $* *$ & $* *$ & $* *$ & $* *$ & $* *$ & NS \\
\hline $\mathrm{C} \times \mathrm{P} \times \mathrm{CV}$ & $* *$ & $* *$ & $* *$ & $* *$ & $* *$ & $* *$ & $* *$ \\
\hline
\end{tabular}

Ns, *,**Nonsignificant or significant at $P<0.05$ or $P<0.01$, analysis of variance.

to general patterns for all variables as a result of the planting date $\times$ cultivar $\times$ culture method interaction (Table 3).

Marketable plant measures. The general trend was for more marketable plants to be produced in the greenhouse than in the hoop house for all cultivars at each planting date. Exceptions were: for the 15 Sept. 2010 planting date, more marketable plants were produced in the hoop house for 'Evergreen Hardy White' and for 'Deep Purple', numbers produced were similar regardless of culture method; for the 15 Oct. 2010 planting date, numbers of marketable plants produced by 'Evergreen Hardy White' were similar regardless of culture method; for the 15 Dec. 2010 planting date, numbers of marketable plants produced by 'Nabechan F1' were similar regardless of culture method; for the 15 Apr. 2011 planting date, numbers of marketable plants were similar for ' $\mathrm{Ev}$ ergreen Hardy White' and 'Deep Purple' regardless of culture method, but the number of marketable plants produced by 'Nabechan F1' in the hoop house were greater than in the greenhouse, and for the 15 July 2011 planting date, no harvestable plants were produced for all cultivars regardless of culture method and this was also the case for 'Deep Purple' sown on 15 Aug. 2011.

The trend for marketable yield followed that for marketable number of plants. The single exception was for the 21 Jan. 2011 planting when, although marketable numbers of plants for 'Nabechan F1' were similar, marketable yield was lower in the greenhouse than in the hoop house. The trend for yield $/ \mathrm{m}^{2}$ also followed that for other marketable measures. The exceptions were: for 'Evergreen Hardy White' sown on 14 Oct. 2010 in which marketable number and yield were similar but yield $/ \mathrm{m}^{2}$ was higher for plants produced in the greenhouse than in the hoop house. For 'Nabechan F1' sown on 21 Jan. 2011, numbers of marketable plants were similar but their yield in the hoop house was higher and there was no difference in yield $/ \mathrm{m}^{2}$ regardless of culture method. Under greenhouse conditions, yields of at least $1 \mathrm{~kg} \cdot \mathrm{m}^{-2}$ were realized for all but the July planting date. The planting dates from September through December and February through June appeared to produce among the highest yields with the March planting date appearing to produce the most yields. In the hoop house, the September and May planting dates produced what appeared to be the highest yields.
Cull measures. In most cases, numbers of cull plants were lower under hoop house conditions; in 16 instances, there was no difference, but for 'Deep Purple', sown on 16 Nov. 2010, there were more cull plants produced in the hoop house. For cull yield, there were generally no differences over planting dates between types of culture method for cultivars. In 12 instances, there was less cull yield in the hoop house, and in one instance, there was more cull yield in the hoop house (planting date 16 Nov. 2010, 'Evergreen Hardy White').

Top weight above $20 \mathrm{~cm}$. There was either no difference in top weight above $20 \mathrm{~cm}$ values for plants regardless of culture method or values were lower in the hoop house than for plants in the greenhouse.

\section{Discussion}

The greenhouse and hoop house production environments are by definition different and each has limitations and benefits. That yield could be affected by environmental conditions was exemplified by the physical damage done to the hoop house and yield by high winds and high air temperatures. High and low temperatures in the summer months, in which part of the experiment was conducted, exceeded records for the region and in the hoop house, where plants were able to develop; marketable yields were reduced or not realized. With sides raised during hotter months, there is little difference in air temperature in and outside of the hoop house. With sides lowered in the cooler months, the hoop house retains some of the heat acquired during the day and primarily protects against frost. Without additional heating, protection from subfreezing temperature is minimal. Use of other inputs to include, but not be limited to, shading and heating may improve the yield of bunching onion using hoop house culture.

The greenhouse environment, which was not modified throughout the experiment, did not provide complete protection from environmental conditions affecting plant development. The greenhouse cooling was not able to reduce air temperatures below $37^{\circ} \mathrm{C}$ during the hottest part of the day during the hottest months. Set point nighttime temperatures were able to be maintained. Except for the 15 July 2011 planting date, some marketable yield was realized. The other planting dates generally produced at levels that were as good as, or better than, the 1 to $1.23 \mathrm{~kg} \cdot \mathrm{ha}^{-1}$ realized for field production (Anonymous, 2002). Cultivar appears to affect yield and for most planting dates, one or more of the cultivars produced at levels in the greenhouse above those of field-grown crops and the growing season was extended to provide bunching onions in most months. The efficacy of the hoop house to extend the growing season appears to be less; the result of the minimal control over climate.

Time until most marketable size plants were produced far exceeded the 60 to $65 \mathrm{~d}$ listed by the supplier that would occur under field conditions. Longer production times have to be weighed against the cost of realizing the possible yield. Greenhouse production exposes plants to as much light as possible and plant physiological responses, sometimes detrimental, respond to amount and type of light (Madrid et al., 1999; Montané et al., 1999). The type of glass allows for various degrees of light filtering. The 2-fold, or more, increase in production time may reflect the unmodified growing conditions in the greenhouse.

Options for maximizing yield of bunching onions under greenhouse conditions will likely be related to understanding the appropriate production system that could involve: amount of fertilizer, amount and timing of irrigation, and climate control to include heating/cooling regimes, duration of supplemental light, and use of shadecloth. When shade was used under tropical conditions in the field, bunching onion yield increased, or was unaffected, depending on time of year (Wolff and Coltman, 1990). In a protected environment, effects of shade might have an identifiable impact because other variables could be better controlled. Various types, and thicknesses, of plastic exist for covering hoop houses with different filtering capacity. This can also affect plant development and vary time to marketable harvest. Cultural methods used for production in protected environments need to be examined so that plants produce appropriate top growth and bulb sizes. Although leaf tissue contributes to plant development through photosynthesis, tissue produced above the $20 \mathrm{~cm}$ height might be considered economically unimportant biomass. If leaf height could be controlled, time to harvest of appropriatesized plants might be affected. Plants grown under hoop house conditions generally were shorter than for greenhouse-grown plants but this did not appear to benefit yield when compared with greenhouse-grown plants. Also, the volume of unmarketable plants may be a concern because the biomass will have to be disposed of.

A possible benefit to growing this crop is its use in "Farm to School" and extended season programs. Hoop house culture is more susceptible to environmental conditions with weather extremes having detrimental effects to the extent of crop failure, which occurred for half of the planting dates. It appears that the greenhouse environment is better suited for this practice because some yield would be realized during summer months when schools 


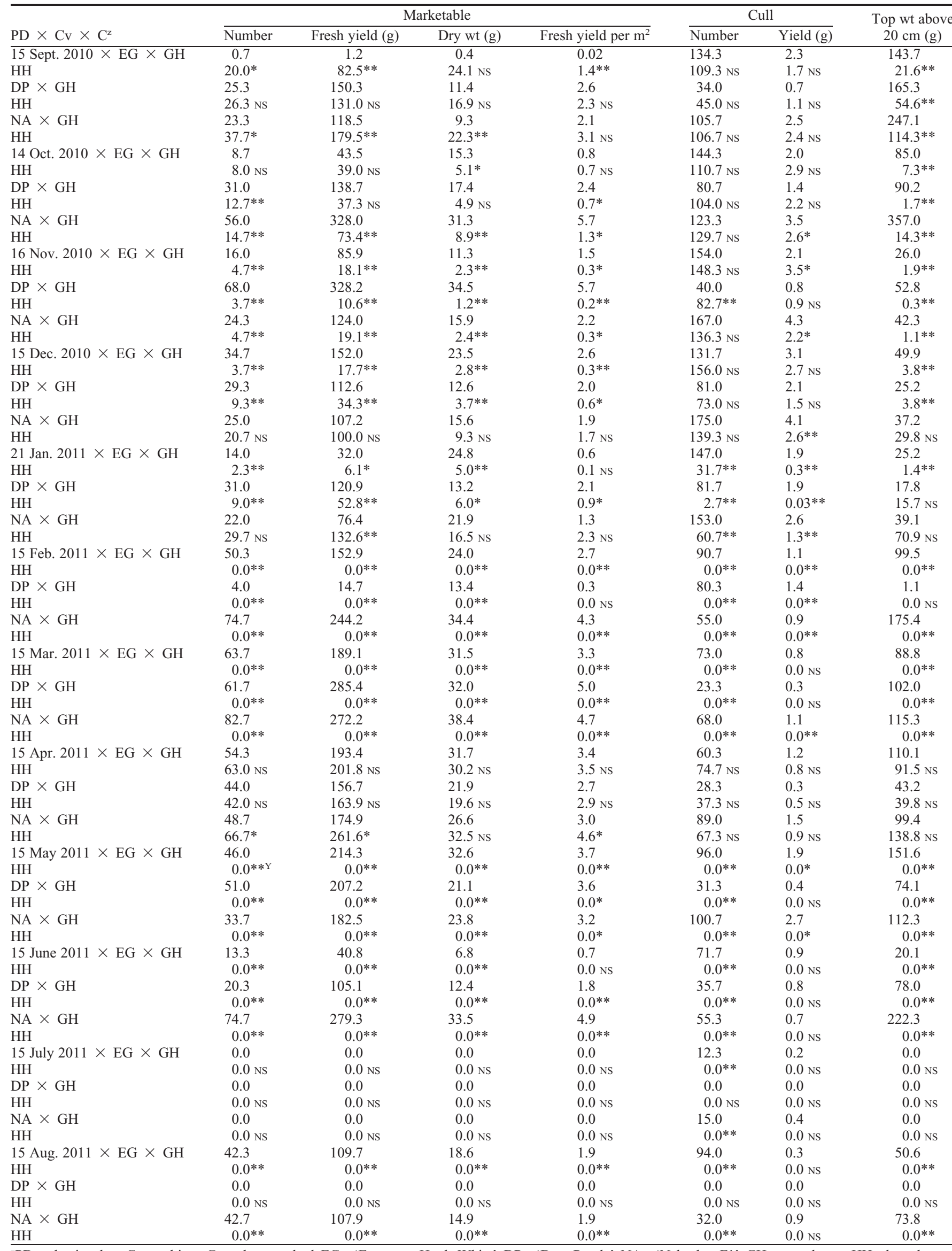

${ }^{\text {zPD }}=$ planting date $\mathrm{Cv}=$ cultivar; $\mathrm{C}=$ culture method; $\mathrm{EG}$ = 'Evergreen Hardy White'; $\mathrm{DP}$ = 'Deep Purple'; NA = 'Nabechan F1'; $\mathrm{GH}=$ greenhouse; HH = hoop house. ${ }^{y}$ For purposes of analysis, the value " 0 " was assigned when there was no marketable yield produced.

Ns, *, **Nonsignificant or significant at $P<0.05$ or $P<0.01$, least squares means analysis. 
have extended sessions or if a year-long school session is instituted. Greenhouses provide more flexibility in controlling the growing environment but costs will be higher. Although the ability to control the environment is available, extremes in summer and winter months can affect temperature control efficiency in the greenhouse; in one instance crop failure occurred. Because chances of producing a crop are higher, use of a greenhouse for extended season production of bunching onions appears to be warranted and may be improved with modification of the growing environment.

\section{Literature Cited}

Anonymous. 2002. Green bunching onions. Allium fistulosum and Allium cepa. Commercial vegetable production guides. Oregon State
University, Corvallis, OR. <http://nwrec.hort. oregonstate.edu/oniongr.html $>$.

Boyhan, G.E., D.M. Granberry, and W.T. Kelley. 2009. Green onions. Commercial vegetable production. Cooperative Extension, The University of Georgia, Tifton, GA. <http://www. caes.uga.edu/publications/pubDetail.cfm?pk id $=6424>$.

Broome, A. and E.B. Peffley. 2005. Effect of planting density on the ontogeny of three Allium species. HortScience 40:875 (abstract).

Hodges, L. 2004. Growing scallions (green onions) for market gardeners. Paper 76. Historical materials from University of Nebraska Extension, Lincoln, NE. $<$ http//digitalcommons.unl.edu/ extensionhist $/ 76>$.

Madrid, R., F. Navarro, I. Collados, C. Egea, and A.L. Alarcon. 1999. Development of colour in red pepper fruits in soilless culture. J. Hort. Sci. Biotechnol. 74:175-180.

Montané, M.-H., B. Petzold, and K. Kloppstech. 1999. Formation of early-light-inductible-protein complexes and status of xanthophyll levels under high light and cold stress in barley (Hordeum vulgare L.). Planta 208:519-527.

Russo, V.M. 2004. Greenhouse-grown transplants as an alternative to bare-root transplants for onion. HortScience 39:1267-1271.

Russo, V.M. 2006. Biological amendment, fertilizer rate, and irrigation regime for organic bell pepper transplant production. HortScience 41: 1402-1407.

Shrefler, J., M. Taylor, W. Roberts, and C. Webber, III. 2011. Onion transplant production system for Oklahoma. HortScience 46: S42-S43.

U.S. Department of Agriculture, Agricultural Marketing Service. 1947. United States standard grades for Common Green Onions. Washington, DC.

Wolff, X.Y. and R.R. Coltman. 1990. Productivity under shade in Hawaii of five crops grown as vegetables in the tropics. J. Amer. Soc. Hort. Sci. 115:175-181. 